\title{
歯周病の進行に咬合性外傷が果たす役割 Role of occlusal traumatism in the progression of periodontal disease
}

\author{
北海道大学大学院歯学研究科 口腔健康科学講座 \\ 坂上竜資
}

\begin{abstract}
歯周病における歯周組織破壊のメインプロセスは、プラークによる炎症性破壊であるが、重度の歯 周炎では咬合性外傷が重要な役割を果たしているのではないかと考えられる。歯周病患者にプラーク コントロールを十分に行わせ、歯周外科を行ったとしても、それで全ての問題が解決するわけではな く、咬合性外傷が重要な役割をしていると思われる症例に数多く遭遇する。しかし現在の歯周病学の 分野では、国内、国外とも炎症性破壊に関する研究が主流を占め、咬合性外傷に関する研究はきわめ て少ないのが現状である。そこで本シンポジウムでは、歯周病による歯周組織破壊に咬合性外傷が与 える影響、役割について当教室での一連の研究を含めて考えてみたい。また、咬合性外傷を引き起こ 寸原因として注日されているBruxismについても討論したいと考えている。
\end{abstract}

1.歯周組織破壊のメカニズムについて

歯周組織に咬合性外傷が生じる成因は、歯に加わる外力（咬合力）と、それに刘する歯周組織の適 忠力の 2 つに分けて考えられる。1970〜80 年代には、炎症と合併した場合でも咬合性外傷はアタッチ メントロスは生じないとする説をPolson らが発表し、歯槽骨支持の減少した歯に摇さぶりカが加わっ た時にはアタッチメントロスを起こすとするLindhe らと論争になったが、十分な結論が得られないま ま今日に至った経緯がある。

当教室ではこれまで、炎症と咬合性外傷との合併による歯周組織破壊のメカニズムの解明を日的と して、多くの動物実験を行ってきた。(1)本間はサルにソフトダイエットを与え、臼歯部に不適合クラ ウンを装着した。しかし誘発された炎症の程度は軽度で、強い咬合性外傷を与えてもアタッチメント ロスを認めなかった。(2)浅野は、サルの臼歯歯䅡部に綿系結紮を行って強い炎症を起こすとともに、 水平と垂直方向の二種類の強い外傷を与えた結果、アタッチメントロスを伴う高度の歯周組織破壊が 生じ、骨縁下ポケットが形成されることを観察した。(3)畢らは、炎症と外傷の程度の觅が結果の違い を生じる理由であると考え、炎症と外傷の程度を変えて同様の実験を行った。その結果、炎症と外傷 が合併ししかもその両者が強いほど、歯槽骨の吸収とアタッチメントロスは增加し、残存する歯間水 平線維層の幅は減少した。歯間水平線維が強い炎症により破壊され減少すると、外傷力によってさら に線維の断裂や血管の圧迫出血が生じ、炎症性細胞が浸潤しやすくなり、アタッチ,メントロスが進行 するのではないかと考えられた。(4)一方、岡は実験的歯周炎に咬合性外傷が加わることで歯周ポケッ トの細菌丵が変化するかどうかをサルを用いて調べ、外傷が加わらない場合と比べて細菌学的には大 きな差がないことを報告した。炎症に外傷が加わった時に高度な歯周組織破壊を起こした原因として、 ポケット内の細菌叢の差よりも、咬合性外傷が大きな影響を与えたと苊えられた。

我々は咬合性外傷による組織破壊のメカニズムを解明するため、さらに多角的に研究を進めている。 本シンポジウムでは垂直性骨吸収との関係や、咬合性外傷が加わった部位での破骨細胞／破歯細胞の 動態など我々の最新の知見を報告したい。

2. Bruxism による歯周組織破壊について

Bruxismの発生のメカニズムは未だ科学的に十分解明されておらず、従来の臨床的診查や、問診によ る自覚症状の有無では適切な診断は困難である。池用らは患者の口腔内にオクルーザルスプリントを 装着させ、その摩耗程度から診断する方法を報告している。大森らはこの方法を心用して、Bruxism 習癖のある患者においては統計的にみて根分岐部病変がより悪化することを報告した。当教室では、 スプリントによる診断法に加えて、筋電計（患者が自宅に持ち师り夜間の Bruxism を記録寸る装置） を用いることにより、Bruxismをより多角的に診断し、Bruxism と歯周病との関連を明らかにして歯周 病患者の治療方針に組み込むことを日指しており、これらについても述べてみたい。 